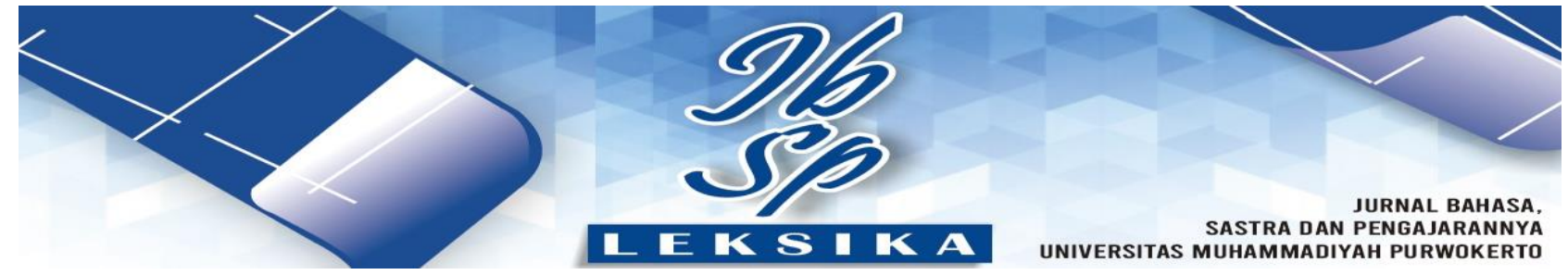

\title{
Lexical density and variation in Indonesian folklores in English student textbooks: an SFL study
}

\author{
Eva Tuckyta Sari Sujatna, Heriyanto, and Andri Setiadi* \\ The Graduate School Faculty of Cultural Sciences, Universitas Padjajdaran, Bandung, Indonesia
}

\begin{abstract}
This study aims to study the lexical density and lexical variation in Indonesian folklore narrative texts in English textbooks for grade X which were published by the Ministry of Education and Culture of The Republic of Indonesia. This study uses qualitative method since this study focuses on lexical density and lexical variation in the texts from the textbooks. This study applies the theory of Systemic Functional Linguistics based on lexical density theory of Ure (1971) which was refined by Halliday (1985) and the theory of lexical variation of Castello (2008). In addition, Gunning Fog Index and Estimated Reading Grades by Heydari (2012) are also applied to help measure suggested reading grades of the texts. The data are three narrative texts about Indonesian folklore from Bahasa Inggris: third edition (2017) and Interlanguage (2008) textbooks. This study revealed that the texts vary in terms of their lexical density and lexical variation. Moreover, in some of the texts, their lexical variation does not go in line with their lexical density and affect the difficulty level of the texts to be comprehended. This study also revealed that the texts vary in terms of Gunning Fog Index and many of the texts are suggested for lower graders.
\end{abstract}

Keywords: lexical density, lexical variation, Indonesian folklore

Article History: Recieved 27 Jul 2021, Final revision 23 Aug 2021, Published 31 Aug 2021

\section{Introduction}

Textbooks play an important role in teaching and learning processes both for formal and informal schools. This makes textbooks and classroom teaching and learning processes are inseparable. All subjects at schools need textbooks to make sure the teaching and learning process goes as planned, including English, Math, Biology, etc. Not only the use of textbooks in teaching and learning processes can help both teachers and their students in teaching and learning processes but the use of good quality textbooks can also help boost the outputs of the students. This is in line with Watts-Taffe, Gwinn, Johnson \& Horn (2003); Dole \& Osborn (2003); Reys, Reys \& Chávez (2004); Apple (1991); Elliot \& Woodwart, (1990) as cited by Putra and Lukmana (2017) who argue that textbooks have been considered as the key role of school education. This point is supported by the research of Radencich (1995) as cited by Putra and Lukmana (2017) who found out that $95 \%$ of teachers rely on textbooks they use in planning their lessons. At this point, those researchers point out that textbooks are essential for teaching and learning processes as media to plan teachers' lessons and to facilitate students' learning.

The quality of textbooks is a major part in determining the success of education system. Good quality textbooks can help boost students' output. Moreover, the difficulty in comprehending texts varies depending on the variety of text features (Beck, McKeown \& Worthy, 1995: 220). Thus, various problems may occur if there are not any standards in choosing the appropriate texts to be involved in school textbooks due to the difficulty level in comprehending them. By setting certain standards in choosing or creating the texts for school textbooks, it will help teachers to adjust the difficulty level of comprehending the texts with the levels of education. Those standards of school textbooks can be used as parameters in selecting suitable textbooks to be used in certain classes. The standards are also useful for school textbook writers to maintain the quality of their textbooks.

To help overcome the problems, the Ministry of Education and Culture of The Republic of Indonesia, along with curriculum 2013, has published Buku Sekolah Elektronik (Electronic

*Corresponding author: Andri Setiadi, Fakultas Ilmu Budaya, Universitas Padjadjaran, Jalan Raya Bandung -

Sumedang Km. 21 Jatinangor - Sumedang 45363. Email address: ndri.shatyadi@gmail.com.

https://dx.doi.org/10.30595/lks.v15i2.11102 , (c) 2021 Leksika. All rights reserved. 
School Textbooks) online to be used in all state and private schools in Indonesia. The publishing of these online e-books is hoped to help all state and private schools in setting the same standards in their teaching processes. There are five textbooks available in the official website of Ministry of Education and Culture of The Republic of Indonesia.

Lexical density and lexical variation determine the level of readability for the students. This study investigates the 20 narrative texts in the textbooks. These texts can be analyzed using Systemic Functional Linguistics (SFL). This research is aimed to investigate the lexical density and lexical variation in narrative texts in Bahasa Inggris: third edition, Developing English Competencies, and Interlanguage textbooks for grade $\mathrm{X}$ published by the Ministry of Education and Culture of The Republic of Indonesia.

There have been several prior researches related to lexical density in written texts. The first one is the one that has been conducted by Sujatna (2016) entitled Hard word and Lexical Density of the Five Short Stories for Children in Bahasa Indonesia. The data for this research were five short stories for children in Bahasa Indonesia. The result shows that the average of the hard word of the five short stories in Bahasa Indonesia is $21.28 \%$ while the average of their lexical density is $45.23 \%$. The second initial research is the one that is conducted by Nurfithri (2017) entitled Lexical Density in Reading Texts in Twelfth Grade of Senior High School: A Systemic Functional linguistics Study. The subjects of the research were twelfth grade of senior high school textbooks published by Erlangga, YramaWidya, and KementrianPendidikandanKebudayaan. The result shows that the percentage of lexical density in the book published by Erlangga is $54.30 \%$, the percentage of lexical density in the book published by YramaWidya is $55.71 \%$, and the percentage of lexical density in the book published by KementrianPendidikandanKebudayaan is $54.86 \%$. The third initial study is the one that has been conducted by Putra and Lukmana (2017) entitled

\section{Research Method}

This study employs qualitative approach. Fraenkel and Wallen (2009) argue that this approach is applied when the data collected are texts and images. In this study, the data collected are Indonesian folklore narrative texts in Bahasa Inggris: third edition (2017) and Interlanguage (2008) textbooks for grade $\mathrm{X}$ which were published by the Ministry of Education and Culture of The Republic of Indonesia. The data are analyzed descriptively. Polit and Hungler (2010) state that descriptive studiy's main objective is to portray the
The Complexity in Senior High School English Textbooks: A Systemic Functional Perspective. The data used were the texts in English textbooks for senior high schools published by Indonesian Ministry of Education and Culture in 2013. The results show that the textbooks have inconsistent text complexity within each book but there is a consistent pattern of text complexity progression across grade levels.

The prior researches above show that lexical density plays an important role in providing suitable materials, especially reading texts, for students to learn English well. In order to facilitate the students' learning, the percentage of lexical density in the textbooks provided has to be adjusted according to the students' grades at schools. A good proportion of lexical density can help teachers and even the government to set the best curriculum for English subject at schools.

In conclusion, all of the background above motivates the researcher to study the lexical density and lexical variation in Indonesian folklores in Bahasa Inggris: third edition (2017) and Interlanguage (2008) textbooks for grade $\mathrm{X}$ which were published by the Ministry of Education and Culture of The Republic of Indonesia and are used in both state schools and private schools all over Indonesia.

Accordingly, this study is based on narrative texts in Indonesian folklores in the Bahasa Inggris: third edition (2017) and Interlanguage (2008) textbooks for grade $\mathrm{X}$ which were published by the Ministry of Education and Culture of The Republic of Indonesia. In English subject, the quality of the textbooks is often determined by the quality of their reading text and lexical density and lexical variation determine the level of readability for the students. Textbooks which contain too difficult or too easy texts to comprehend can cause problems that detain the teaching and learning processes that lead to not optimal outputs of the students. Thus, this study focuses on lexical density and lexical variation in the narrative texts from the four textbooks.

characteristics of persons, situations, or groups, and/or the frequency which certain phenomena occur. In this study, the phenomenon that researcher intend to portray is the one occurs in narrative texts in Bahasa Inggris: third edition (2017) and Interlanguage (2008) textbooks for grade $X$ which were published by the Ministry of Education and Culture of The Republic of Indonesia.

This study employs qualitative approach. Fraenkel and Wallen (2009) argue that this approach is applied when the data collected are 
texts and images. In this study, the data collected are Indonesian folklore narrative texts in Bahasa Inggris: third edition (2017) and Interlanguage (2008) textbooks for grade $\mathrm{X}$ which were published by the Ministry of Education and Culture of The Republic of Indonesia. The data are analyzed descriptively. Polit and Hungler (2010) state that descriptive studiy's main objective is to portray the characteristics of persons, situations, or groups, and/or the frequency which certain phenomena occur. In this study, the phenomenon that researcher intend to portray is the one occurs in narrative texts in Bahasa Inggris: third edition (2017) and Interlanguage (2008) textbooks for grade $X$ which were published by the Ministry of Education and Culture of The Republic of Indonesia.

\section{Result and Discussion Results}

Lexical density is a term that is used in text analysis. Halliday (1985: 63) defines lexical density as the number of lexical items in the proportion of the number of running words. The analysis of the study focuses on the lexical density contained in narrative texts in English student textbooks for grade $X$. The writer uses the suggestion by Sujatna
Data are important in a research because they are the source of information to be used in answering the research questions. Fraenkel and Wallen (2009) support this statement by stating that data refer to kinds of information that researchers obtain on their research. This study collects the data from Bahasa Inggris: third edition (2017) and Interlanguage (2008) textbooks for grade $X$ which were published by the Ministry of Education and Culture of The Republic of Indonesia. They are downloaded from the website of bse.kemendikbud.go.id which is the official website of Indonesian Ministry of Education and Culture.

(2017) and Sholichatun (2011) who state that a text is considered having low lexical density ranges from $40 \%$ to $50 \%$, a text is considered having quite lexical density ranges from $50 \%$ to $60 \%$, and a text is considered having a high lexical density ranges from $60 \%$ to $70 \%$. In analyzing the data, the researcher applies the application which is available online in https://www.analyzemywriting.com.

Text 1

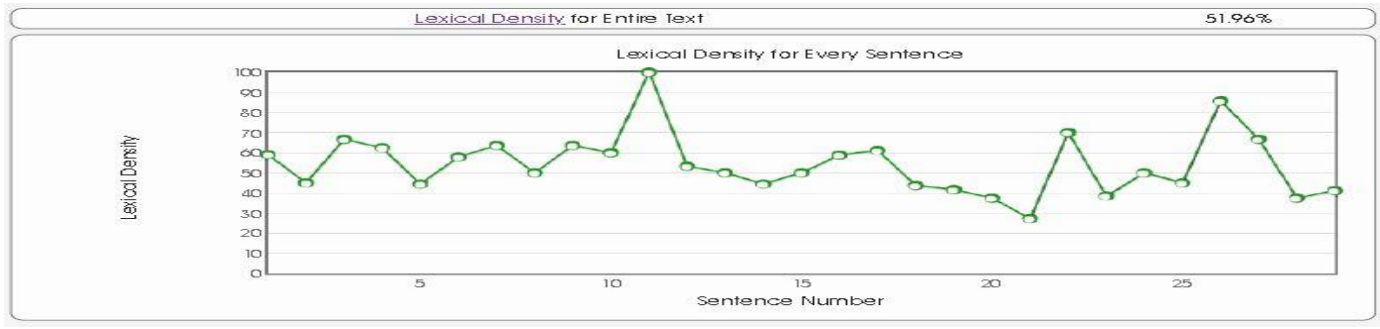

Figure 1. Lexical density in Text 1 (The Legend of Malin Kundang)

From the chart above, we can see that the lexical density of this text ranges from $27.27 \%$ to $100 \%$. The lexical density of the whole text of narrative text 1 (The Legend of Malin Kundang) is $51.96 \%$. The text which has the range of lexical density between $50 \%-60 \%$ is considered having a quite lexical density. In addition to this, the text has balanced content-carrying words as a proportion of all words, so it strengthens the conclusion that the text has a quite lexical density level. It can also be implied that the text has a fair grammatical intricacy. These two findings lead to a conclusion that the text possesses somewhere between written and spoken language characteristics. Thus, this text is considered having medium level of difficulty to understand.

The following is the Lexical Variation_found in the Text 1 (The Legend of Malin Kundang) that applies the Lexical Diversity Calculator application which is available online in the website of https://www.textinspector.com

\begin{tabular}{ccc}
\hline $\begin{array}{c}\text { Total Unique Lexical } \\
\text { Item }\end{array}$ & Total Lexical Items & Lexical Variation \\
\hline 179 & 401 & 0.45 \\
\hline
\end{tabular}

The followings are the details of the distribution of parts of speech from the narrative text 1 


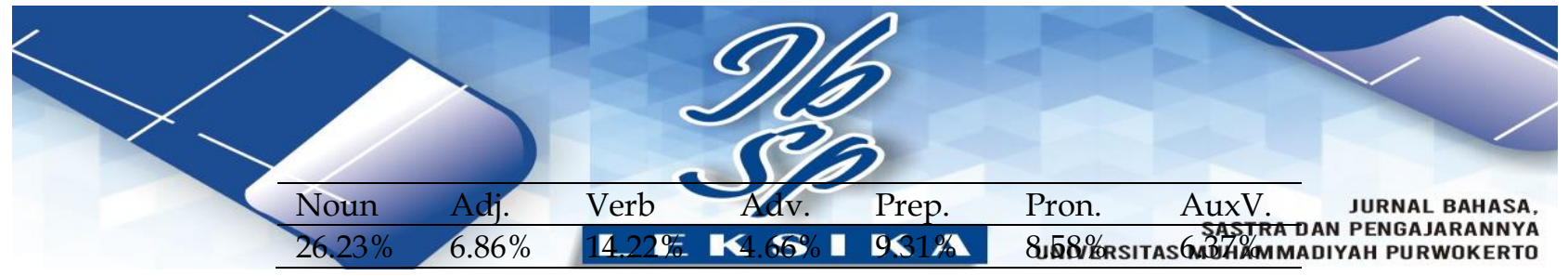

The lexical variation in narrative text 1 is 0.45 . Noun is the major parts of speech involved the text. The low lexical variation decreases the difficulty level of the text based on its lexical density.

The text consists of 408 total words from 29 sentences. So, the text has the average number of words in sentences of 14.07. There are 16 words of three or more syllables, such as the word thunderstorm, apologize, etc. So, the percentage of words of three or more syllables is $3.92 \%$. The Gunning Fog Index of this text is 6.833. Thus, according to estimated reading grades suggested by Heydari (20120 in Sujatna (2019), the text is suggested for sixth grade students.

Text 2

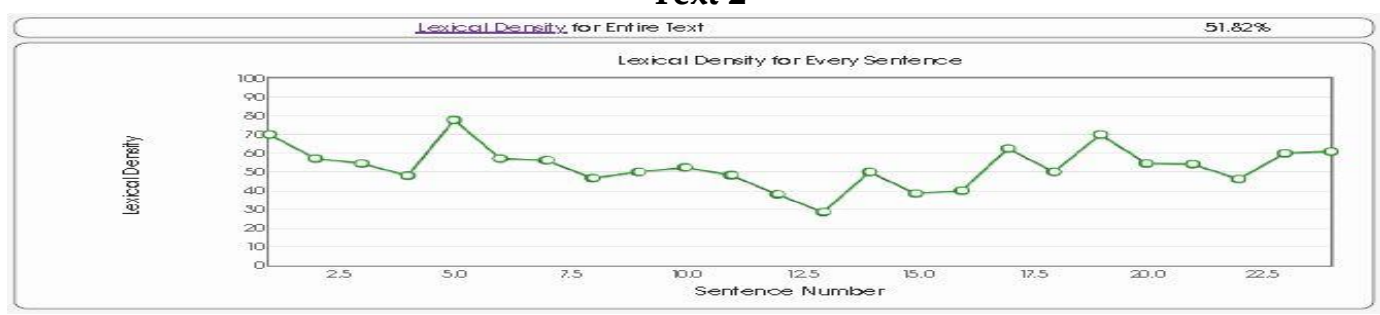

Figure 2. Lexical density in Text 2 (Queen Aji Bidara Putih)

The chart shows that the lexical density of this text ranges from $28.57 \%$ to $77.78 \%$ The lexical density of the whole text of narrative text 2 (Queen Aji Bidara Putih) is $51.82 \%$. The text which has the range of lexical density between $50 \%-60 \%$ is considered having fair lexical density. In addition to this, the text has balance content-carrying words as a proportion of all words, so it strengthens the conclusion that the text has medium lexical density level. It can also be implied that the text has fair grammatical intricacy. These two findings lead to a conclusion that the text possesses somewhere between spoken and written language characteristics. Thus, this text is considered having medium level of difficulty to understand.

The following is the Lexical Variation found in the Text 2 (Queen Aji Bidara Putih) that applies the Lexical Diversity Calculator application which is available online in the website of https://www.textinspector.com

\begin{tabular}{ccc}
\hline $\begin{array}{c}\text { Total Unique Lexical } \\
\text { Item }\end{array}$ & Total Lexical Items & Lexical Variation \\
\hline 193 & 385 & 0.50 \\
\hline
\end{tabular}

The followings are the details of the distribution of parts of speech from the narrative text 2

\begin{tabular}{lllllll}
\hline Noun & Adj. & Verb & Adv. & Prep. & Pron. & AuxV. \\
\hline $29.17 \%$ & $5.21 \%$ & $14.32 \%$ & $3.13 \%$ & $11.2 \%$ & $5.73 \%$ & $4.95 \%$ \\
\hline
\end{tabular}

The lexical variation in narrative text 17 is 0.50 . Noun is the major parts of speech involved the text. The text has a fair level of lexical variation so it is considered balance and does not significantly increase nor decrease the difficulty level of the text based on its lexical density.

The text consists of 379 total words from 26 sentences. So, the text has the average number of words in sentences of 14.58 . There are 25 words of three or more syllables, such as the word centipedes, information, etc. So, the percentage of words of three or more syllables is $6.60 \%$. The Gunning Fog Index of this text is 7.232. Thus, according to estimated reading grades suggested by Heydari (20120 in Sujatna (2019), the text is suggested for seventh grade students.

Text 3

*Corresponding author: Andri Setiadi, Fakultas Ilmu Budaya, Universitas Padjadjaran, Jalan Raya Bandung -

Sumedang Km. 21 Jatinangor - Sumedang 45363. Email address: ndri.shatyadi@gmail.com.

https://dx.doi.org/10.30595/lks.v15i2.11102 , (c) 2021 Leksika. All rights reserved. 


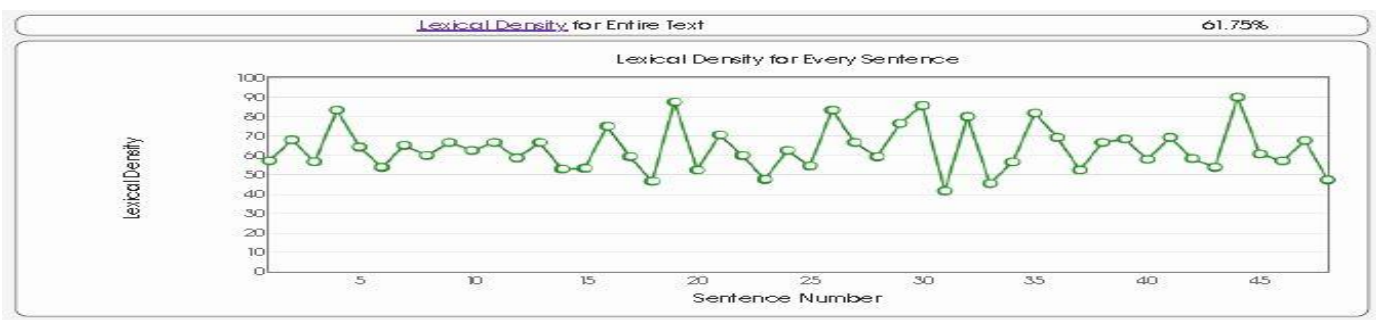

Figure 11. Lexical density in Text 3 (The Legend of Princess Loro Jongrang)

The chart shows that the lexical density of this text ranges from $41.67 \%$ to $90 \%$. The lexical density of the whole text of narrative text 3 (The Legend of Princess Loro Jongrang) is $61.75 \%$. The text which has the range of lexical density above $60 \%$ is considered having high lexical density. In addition to this, the text has more content-carrying words as a proportion of all words, so it strengthens the conclusion that the text high lexical density level. It can also be implied that the text has low grammatical intricacy. These two findings lead to a conclusion that the text possesses written language characteristics. Thus, this text is considered having high level of difficulty to understand.

The following is the Lexical Variation_found in the Text 3 (The Legend of Princess Loro Jonggrang) that applies the Lexical Diversity Calculator application which is available online in the website of https://www.textinspector.com.

\begin{tabular}{ccc}
\hline $\begin{array}{c}\text { Total Unique Lexical } \\
\text { Item }\end{array}$ & Total Lexical Items & Lexical Variation \\
\hline 204 & 477 & 0.43 \\
\hline
\end{tabular}

The followings are the details of the distribution of parts of speech from the narrative text 3

\begin{tabular}{lllllll}
\hline Noun & Adj. & Verb & Adv. & Prep. & Pron. & AuxV. \\
\hline $36.55 \%$ & $2.48 \%$ & $15.54 \%$ & $7.18 \%$ & $10.44 \%$ & $4.83 \%$ & $5.48 \%$ \\
\hline
\end{tabular}

The lexical variation in narrative text 3 is 0.43 . Noun is the major parts of speech involved the text. The text has low level of lexical variation so it decreases the difficulty level of the text based on its lexical density.

The text consists of 765 total words from 48 sentences. So, the text has the average number of words in sentences of 15.93. There are 68 words of

\section{Discussion}

This study is based on narrative texts in Indonesian folklores in the Bahasa Inggris: third edition (2017) and Interlanguage (2008) textbooks for grade $\mathrm{X}$ which were published by the Ministry of Education and Culture of The Republic of Indonesia. In English subject, the quality of the textbooks is often determined by the quality of their reading text and lexical density and lexical variation determine the level of readability for the students. Textbooks which contain too difficult or too easy texts to comprehend can cause problems that detain the teaching and learning processes that lead to not optimal outputs of the students. Thus, this study focuses on lexical density and lexical variation in the texts from the textbooks and whether the lexical density and the lexical variation found in Indonesian folklores narrative three or more syllables, such as the word meditated, immediately, etc. So, the percentage of words of three or more syllables is $8.66 \%$. The Gunning Fog Index of this text is 9.440. Thus, according to estimated reading grades suggested by Heydari (20120 in Sujatna (2019), the text is suggested for high school freshman grade students.

texts in the student textbooks meet the requirement to be used for grade $X$.

Lexical density is a major factor that determine the level of difficulty of a text to be comprehended by its readers. A text with high lexical density means that the text has more content-carrying words in the proportion of the whole words in the text. It shows that the text has high difficulty level to be comprehended. On the other hand, lexical variation or lexical diversity is related to the frequency of unique content-carrying words in the proportion of all content-carrying words. The highest the lexical variation index is, the less repetition of content-carrying words the text has. High repetition will reduce the difficulty level of the texts and vice versa. A text may have really high lexical density but low lexical variation. In this case, the low lexical variation decreases the 
difficulty level of the text to be comprehended. In brief, analyzing both lexical density and lexical variation of a text can give us a better picture in measuring the difficulty level of a text.

In addition to this, the term fog index also sometimes called Gunning fog index, as cited by Sujatna (2019), is introduced by Robert Gunning who founded the first consulting firm specializing in readability in1994 and it still used by writers up to the recent times to measure their writings. The result of the calculation of fog index can be used as a reference in deciding the difficulty level of a text as well as in estimating reading as in Heydari

\section{Conclusion}

In conclusion, the lexical density found varies in the three Indonesian folklore narrative texts. The first folklore, The Legend of Malin Kundang, has $51.96 \%$ of lexical density. This text has a quite lexical density so it is also considered having medium difficulty level to understand. On the other hand, has 0.45 of lexical variation index. This low level of lexical variation shows that it has high frequency of repetition of lexical items and will decrease the difficulty level of the text to comprehend even though this text has a quite lexical density. The second folklore, Queen Ahi Bidara Putih, has $51.82 \%$ of lexical density. Since this text also has a quite lexical density, it is considered having medium difficulty level to understand. On the other hand, the second folklore has 0.50 of lexical variation index. Since this text also has a quite lexical density and a quite lexical variation index, it is considered having medium difficulty level to understand. The third folklore, The Legend of Loro Jonggrang, has $61.75 \%$ of lexical density. This text has really high lexical density so it is considered difficult to comprehend. On the other hand, the second folklore has 0.50 of lexical

\section{References}

Abbot, H.P. (2002). The Cambridge Introduction to Narrative. United Kingdom: Cambridge University Press.

Apple, M. (1991). The Culture and Commerce of the textbook. In M. Apple and L. Christian-Smith (Eds.), The Politics of the textbook (pp. 147 - 162). New York: Routledge.

Beck, I.L., McKeown, M.G. \& Worthy, J. (1995). Giving a Text Voice Can Improve Students' Understanding. Reading research Quarterly, 20(2), 220-238.

Brown, Keith \& Miller, Jim. (2013). The Cambridge Dictionary of Linguistics. Cambridge University Press.
(2012) in Sujatna (2019). The estimated reading grades by Heydari (2012) are used to measure reading grades for EFL learners (Zamanian and Heydari, 2012).

Meanwhile, from the result of the analysis, it can be seen that high lexical density is not always followed by high lexical variation and gunning fog index. Furthermore, a text may have both high lexical density and high lexical variation but is not hard enough for certain degrees based on its gunning fog index and estimated reading grades. So it is important to involve more aspects in selecting or creating a text for students.

variation index. Since this text also has a quite lexical density and a quite lexical variation index, it is considered having medium difficulty level to understand.

There are some limitations for teachers in selecting suitable texts for their students of certain grades. Indonesia does not have its own parameters to help book authors and teacher in creating and selecting suitable texts for certain grades in terms of text readability including lexical density and lexical variation. Gunning fog index and estimated reading grades by Heydari (2012) that can be used in estimating reading grades for EFL learners can help us in selecting better texts for certain grades. Below are the estimated reading grades of narrative texts based on gunning fog index and estimated reading grades by Heydari (2012). The first folklore has 6.833 gunning fog index and it is suggested for sixth grade students according to the gunning fog index that the text has. The second folklore has 7.232 gunning fog index and it is suggested for seventh grade students. The third folklore has 9.440 gunning fog index and it is suggested for high school freshman students according to the gunning fog index that the text has.

Bruce, B. \& Rubin, A. (1988). Readability Formulas: Matching Tool and Task. In A. Davison and G.M. Green (eds). Linguistic Complexity and Text Comprehension. New Jersey: Lawrence Erlbaum Associates, Publishers, 5-22.

Castello, E. (2008). Text Complexity and Reading Comprehension tests. Bern: International Academic Publishers.

Creswell, John W. (1994). Research Design: Qualitative and Quantitative Approaches. Sage Publication.

Daller, H., van Hout, R., \& Treffers-Daller, J. (2003). Lexical richness in the spontaneous speech of bilinguals. Applied Linguistics, 24/2, 197222.

Dole, J.A. \& Osborn, J. (2003). Elementary Language Arts textbooks: A Decade of Change. In J. Flood, D. 
Lapp \& J.R. Squire (Eds.), Handbook for research on Teaching the English Language Arts (pp. 631639). New York: Macmillan.

Elliot, D. \& Woodward, A. (Eds.). (1990). Textbooks and Schooling in the United States (90th yearbook of the society for the study of education). Chicago: University of Chicago Press.

Eggins, S. (1994). An Introduction to Systemic Functional Linguistics (1st Ed.). Pinter Publishers

Eggins, S. (2004). An Introduction to Systemic Functional Linguistics (2nd Ed.). New York: Continuum.

Fadhillah, Yaumil. (2018). Analyzing Lexical Density of English Reading Texts in Pathway to English Textbook for Senior High School Grade $X$. Ar-raniry State Islamic University.

Fraenkel, Jack R and Wallen, Norman E. (2009). How to Design and Evaluate Research in Education. New York: McGraw-Hill Publication.

Gerot, Linda \& Wignell,Peter (1995). Making Sense of Functional Grammar: An Introductory Workbook. Cammeray, NSW: Antipodean Educational enterprises.

Gibson, T.R. (1993). Towards a Discourse Theory of Abstracts and Abstracting. Nottingham: University of Nottingham.

Gregori-Signes, C. \& Clavel-Arroiti, B. (2003). Analysing Lexical Density and Lexical Diversity in University Students' Written discourse. Procedia Social and Behavioral Sciences 198 ( 2015 ) 546 $-55$

Halliday, M.A.K and Hasan, Ruqaiya. (1976). Cohesion in English. London: Longman Group Limited.

Halliday, M.A.K. (1987). Spoken and Written Modes of Meanings. In R. Horowitz and S.J. Samuels (Eds), Comprehending Oral and Written Language (pp. 55-82). San Diego: Academic Press.

Halliday, M.A.K. (1989). Spoken and Written Language. Oxford: Oxford university Press.

Halliday, M.A.K. \& Martin, J.R. (1993). Writing Science: Literacy and Discursive Power. London: University of Pittsburgh Press.

Halliday, M.A.K. \& Matthiessen, C. (2004). An Introductionto Functional Grammar (3rd Ed.). London: Arnold.

Harmer, J. (1998). How to teach English. United State: Addison Wesley Longman.

Jeffries, Lesley. (2006). Discovering Language:The Structure of Modern English. New York: Palgrave Macmillan.
Hertzberg, M. (2012). Teaching English language Learners in mainstream Classes. Newtown: Primary English Teaching Association Australia.

Johansson, Victoria. (2008). Lexical diversity and Lexical Density in Speech and Writing: A Developmental Perspective. Working Press, 53: 6179

Kwapien, J.J., Drozdz, S.S. \& Orczyk, A.A. (2010). Linguistic complexity: English vs. Polish, text vs. corpus. Acta Physica Polonica, A., 117(4), 716-720.

Lotman, Jurij. (1977). The Structure of the Artistic Text; translated by Gail Lenhoff and Ronald Vroon. Ann Arbor: University of Michigan.

Mufidah, Z. \& Wenanda, D. (2107). Kepadatan Leksikal Buku Ajar Muatan Lokal Bahasa Madura untuk Kelas VI Sekolah Dasar. Madura: University of Trunojoyo Madura.

Nesia, B.H. \& Ginting, S.A. (2014). Lexical Density of English Reading Texts for Senior High School. Medan: FBS Unimed.

Nurfithri. (2017). Lexical Density in Reading Texts in Twelfth Grade of Senior High School: A Systemic Functional linguistics Study.Bandung: Padjadjaran University.

Palinscar, A.S. \& Duke, N.C. (2004). The Role of Text and Text/Reader Interactions in Young Children's Reading Development and Achievement. Elementary School Journal, 105(2), 183-198.

Polit, D.F. and B.P. Hungler. 1991. Nursing Research. Principles and Methods. Philadelphia: J.B. Lippincott Company.

Posner, R. (2004). Basic Task of Cultural Semiotics. (An essay). Berlin : Technical University.

Putra, A.P. \& Lukmana, I. (2017). The Complexity in Senior High Shool English Textbooks: A Systemic Functional Perspective. Bandung: Universitas Pendidikan Indonesia Press.

Radencich, M.C. (1995). Administration $\mathcal{E}$ Supervision of the Reading/Writing Program. Needham Heights, MA: Allyn \& Bacon.

Rahmansyah, Habib. (2012). Grammatical Intricacy and Lexical density of the SMA Student's Textbooks. Medan: English Applied Linguistics Post Graduate Studies State University of Medan.

Rimmer, W. (2008). Putting Grammatical Complexity in Context. Literacy, 42(1), 29-35. Doi:10.1111/j.1467-9345.2008.00478.x. 